\title{
Teenagers' Addiction to Pornography
}

\author{
Dr. Ashwak Saber Nasser \\ University of Mustansiriya/College of Basic Education \\ ashwag.edbs@uomustansiriyah.edu.iq
}

\begin{abstract}
The current research aims to identify the addiction to pornography among teenagers of middle school students. It also aim at detecting addicted to pornography. Furthermore, it attempts to show the differences in pornography addiction according to the gender variable (male-female). The current research sample is (400) middle school students in the elementary schools affiliated to the Third Directorate of Education of Al-Karkh of both sexes ((200) males / (200) females) for the academic year 2018/2019. The researcher built the porn addiction scale consisting of (32) items and extracted validity and consistency for it. The T-test for two independent samples and the T-test for one sample were used, and the results showed: 1- There are significant differences in porn addiction in favor of middle school students. 2- There are statistically significant differences between the mean of males and females on the scale of pornography addiction in favor of males
\end{abstract}

Keywords:

addiction, pornography, teenagers.

Article Received: 18 October 2020, Revised: 3 November 2020, Accepted: 24 December 2020

\section{Part One}

\section{The problem of the study}

Addiction to watching porn is a pathological problem that has only been recognized medically in recent years, and it is no less dangerous to mental health than addiction to heroin, cocaine or other drugs. The addicted person feels that $\mathrm{s} / \mathrm{he}$ is in urgent need of it, and he does not feel balanced and comfortable except when watching pornographic films. Recent American studies have shown that $(8 \%)$ of men and $(3 \%)$ of women in the United States suffer from addiction to pornography, and the addiction is usually found among individuals who have been subjected to emotional deprivation, especially from parents, or have had sexual experiences in early childhood and adolescence. On this basis, dependence on electronic porn is for many a disorder that can have devastating effects on personal well-being, social adjustment, work, sexual life and family relationships (Cavaglion, 2009).

Statistics indicate that (63\%) of adolescents who view pornographic picture pages do not know their parents what they are browsing on the Internet, and studies indicate that most porn material users are between 12 and 17 years old,
(Abu Hindi, 2010: 2). On pornography, they feel hopelessness, depression, anxiety, stress, and a feeling that they are unable to overcome addiction to pornography when needed. In the past, some researchers and scientists have argued that porn addiction does not rise to the risk of drug addiction, and should not be classified as such (Downs, 2005). The study of Paolucci et al. (2000) indicates that the rate of increase in violent and rape crimes increases by $30 \%$ among those dealing with pornography. The rate of decline in marital relations and sexual ability with the wife decreases by $32 \%$. Acceptance and indifference to rape increases by 31\% (Paolucci et al, 2000: 6134).

While Stephen and others (2005) view porn addiction as a problem such as gambling, alcohol and drugs and that it controls people's lives and makes them miserable (Grant, 2014: 395). All this calls for revealing these teenagers to provide counseling and therapeutic assistance to them. In addition, the scarcity of studies about the problem of porn addiction is by itself a problem that requires attention. Thus, the current research problem is summarized in the answer to the 
following question: Do teenagers in middle school suffer from porn addiction?

\section{The study importance}

Internet is the backdrop for a number of critical family problems, such as computer addiction and children's and teenagers' access to Internet pornography. Some parents describe deep family issues as "technological" problems due to the introduction of the computer, while others ignore or reject the potential effects of modern technologies in the occurrence of various psychological and sexual problems. (Oravec, 2000).

Research works have shown that adolescents regularly use pornography on the Internet, and a study (Beyens, Vandenbosch, \& Eggermont, 2015), which was conducted on a sample of (325) teenager aimed to identify the relationship between teenagers' exposure to Internet pornography and its relationship to the timing of puberty and the search for sensation. It aimed to know the potential effects of their exposure to Internet pornography on their academic performance. The results of the study indicated that the timing of puberty and the search for sensation predicted the use of Internet pornography. This makes males with advanced puberty and males with high feelings seek more use of Internet pornography and decline boys' academic performance after 6 months (Beyens et al., 2015).

A study (Baker, 2016) identified the effects of viewing pornography on youth attitudes and behaviors. Through a survey conducted by (218) young people as well as focused group discussions with (23) specialists in teaching in London's overseas schools. This study examines whether young people and teaching professionals are considering using pornography despite it having harmful effects. They felt Schools should integrate teaching about Internet pornography into their educational programs. The results reveal that young adults and teachers see many negative effects of viewing pornography, especially at a young age. Young people and teachers agree that schools should consider the risks associated with viewing Internet.

As indicated (Bloom, Gutierrez, \& Lambie, 2017) , a study was conducted to know the attitudes of counselors and specialists in family and marriage affairs towards erotica. The study sampled (373) counselors and specialists in family and marriage affairs in Florida. The results of the analysis of the trend towards reotica showed that $72.93 \%$ of counselors and specialists in family and marriage affairs support restricting pornography and also trends towards the notion that pornography has an exploitative character.

The study of Hardy, Steelman, Coyne, and Ridge (2013) on the relationship between adolescent religiosity and pornography use involved a sample of 419 adolescents (ages 15-18 years). It was assumed that religiosity (religious comprehension) would protect teenagers from pornography use (occasional and intentional viewing) by increasing self-regulation, conservative attitudes towards pornography, and social control against pornography. Regression analyzes revealed that religious comprehension is negatively related to intentional viewing, and religiosity protects teenagers from intentional exposure to pornography. Psychologists believe that addiction to pornography is similar to Internet addiction, and in many cases, addiction to pornography on the Internet is more than addiction to regular pornography due to its wide availability, clear nature, and privacy in viewing on the Internet. Addicted people also increasingly spend long periods of time searching for pornography on the Internet (Downs, 2005).

Also, the frequent use of pornography has not been sufficiently studied before. In a Swedish opinion poll, (2015) students participated from the age of 18. A group of porn dependents was studied in relation to social background and psychosocial connections. Those dependent on pornography had a more positive attitude towards pornography, and they were more persistently viewing pornography and often displayed advanced forms of pornography. Frequent use has 
also been linked to several behavioral problems. The dependents are more likely to live in a big city, consume more alcohol, have greater sexual desire, and have more sex more often than other boys of the same age. Accordingly, the frequent viewing of pornography is seen as a problematic behavior that needs more attention by both parents and teachers and also addressed in clinical interviews (Svedin, Åkerman, \& Priebe, 2011).

Alpha et al. (2011) indicates that eighteen percent of the study participants had a satisfactory use of the Internet, and that excessive use of the Internet was causing academic, social and personal problems for them. Excessive use of the Internet was a cause of the high level of psychological desire, which led to the lack of sleep, not eating for long periods, limited physical activity, and health and mental problems such as depression, obsessive-compulsive disorder, poor family relationships and anxiety (Alavi, Maracy, Jannatifard, \& Eslami, 2011).

In the study of O'Reilly, Knox, and Zusman (2007), $40 \%$ of students watch pornography once or twice a week, males view pornography more than women, and females who view pornography are viewed as "loose", and threatened through pornography more males.

Carroll Carroll et al. (2008) stated that nearly twothirds $(67 \%)$ of young men and half $(49 \%)$ of young women agree that viewing pornography is acceptable, while nearly 9 out of $10(87 \%)$ are young men. In addition, about a third (31\%) of young women reported using pornography. Mesch (2009) argued that there is a weak correlation between social bonds and porn addiction, just as the addicted to pornography show a risk of deviant behavior.

The Ohwakanoa study (2012) reported that college students in Lagos state had a high level of addiction to pornography. They have a moderate level of psychological, social and academic adjustment. There is a negative relationship between pornography addiction and psychosocial adjustment and a slight positive relationship between pornography addiction and academic adjustment (907-920 et al, 2012: Ohuakanwa)

Wetterneck et al. (2012) affirmed that there is an association between Internet use to obtain pornography and sexual addiction.

Romito and Beltramini (2015) analyzed the exposure to pornography in a sample of (702) Italian teenagers. In the male sample, $11 \%$ were not exposed to pornography, $44.5 \%$ were exposed to non-violent pornography, and $44.5 \%$ were exposed to violent and degrading material. The $60.8 \%$ female students were not exposed to pornography and $20.4 \%$ were exposed to violent material. Also, $18.8 \%$ were exposed to violent and degrading material. Females who were victims of domestic violence were more likely to view violent pornography. Smoking and having friends involved in the sex trade were associated with violent and degrading exposure to pornography. Exposure to violent /degrading pornography is common among teenagers, and exposure to pornography is associated risky behavior. For females, it is associated with a history of abuse (Romito \& Beltramini, 2015).

From the above, the importance of the current research becomes clear in the following:

1. Knowing the causes of any psychological problem is one of the most important developments in the field of diagnosing and treating psychological and sexual problems. This is because of the security in terms of only diagnosing them or studying their symptoms. However, it is also important in terms of defining them and finding their causes to find solutions to develop a treatment for it or alleviate it. It relates to the problems associated with exposure to risky behaviors.

2. The importance of scientific research lies in the lack of Arab research and studies, especially local ones, according to the researcher's knowledge.

\section{The aims of the study}

The study aims to:

1. Learn about pornography addiction among middle school teenagers. 
2. Detect those addicted to pornography.

3. The differences in addiction to pornography are known according to the gender variable (male-female).

\section{Research limits: -}

The current research is carried out in the first intermediate grade in the middle schools of the Third Al-Karkh Education Directorate, the morning study only in the city of Baghdad for the academic year 2018-2019.

Definitions of terms

The researcher defined the following terms- :

First: - Addiction to pornography-

Alavi et al. (2011, p. 395) define addition to pornography as "a psychological and social disorder that leads to withdrawal symptoms, emotional disturbances, problems in social relations and psychological, social, and school difficulties".

It "is the person's desire to watch everything that stimulates the sexual instinct such as pictures, movies, and websites on the Internet, and in which the addict yearns to either see the genitals, or to watch the sexual process. Addiction begins by watching pornographic pictures, then progresses to watching nudity pictures, then watching movies, and other things "(Al-Rifi, 2012: 1).

The researcher defined porn addiction as "a state in which the individual's desire to view erotic visuals is controlled by the sexual instinct, whether these visuals are pictures, movies or websites. The addict person is characterized by a strong desire to look at the genitals of the favorite sex or to see how the sexual process is filmed. Then, the desire turns into more violent scenes, and the addict usually spends long hours on a daily or almost daily basis watching.

In terms of the procedural definition, it is the total score that the respondent gets on the pornography addiction scale.

Second: Teenage:

According to Madani (2008, p. 10), teenage is "as the stage in which sexual development takes place and sexual instincts reach their climax for the first time. It could also be a stage of a biological and social nature alike. Its beginning is characterized by the occurrence of biological changes in males and females and is compatible with these changes and is accompanied by certain social implications". Psychologically, it includes individuals who have completed or passed the stages of childhood, and temporally it includes individuals from 12-18 years old.

According to Al-Najjar (2009, p. 2), "it is a period in which the individual moves from childhood to maturity, beginning with the period of puberty. It continues until the individual becomes sexually mature, e extends from the age of eleven to the early twenties".

\section{Part Two}

Theoretical framework and previous studies

\section{Pornography}

The primary meaning of the English word for pornography goes back to the Greek word (Pron), which denotes an addiction to pornography. It is clear that the meaning of pornography is no longer limited to describing prostitutes or their behavior. It has expanded to include all materials that contain pictures, films and sexual games. It is more appropriate to define it in a number of dimensions through (Al-Zahrani, 2007) as follows:

1 - The functional dimension: According to this dimension, pornography is every action or act used for the purpose of sexual arousal. In this dimension, pornography is defined from the point of view of the users of these materials, especially with regard to the way pornography is used and the response it provokes.

2 - The classification dimension: According to this dimension, pornography is defined as every act that society sees as an immoral sexual act. This definition includes every substance that people think that stimulates sexual thoughts and arousal, and thus these materials fall within the scope of sexual vulgarity, defect, assault and sexual disgust. This definition views pornography from the point of view of a society that rejects such material. 
3 -The qualitative dimension: In this dimension, pornography is defined from the point of view of the authors or producers of these materials, who aim to manufacture, collect and sell sexual pornography that arouse sexual desire in the largest number of men to earn profits.

Also, some pornographic materials contain scenes of violence and present duplicate topics and can be found in moving pictures, magazines, and written works such as books, poetry, stories and novels, audio recordings, etc.

Pornography first arose in Western Europe during the late eighteenth century alongside the emergence of Utilitarianism. The philosophical position emphasizes the importance of something useful over its substance (Ferguson, 2004).

More recently, porn has spread because of the development of the media. The pornography industry is increasing in production and consumption. The rapid technical development and the emergence of CD and DVD display devices, and the presence of the Internet greatly helped the spread pornography. There are also many types of pornographic materials that depend on sexual affiliation and are classified according to people and cultures. Also in the seventies of the twentieth century, pornographic materials such as magazines and pornographic films spread as a result of the sexual revolution in Western countries. In the eighties and with the advent of video devices, this trade increased greatly. At the beginning of the 1990s of the last century, thousands of pornographic sites appeared on the Internet, and many companies began selling pornographic films over the Internet (Lin et al., 2012).

In 1990, Goodman proposed a general definition of all addictions in order to broaden the specific disorders listed in the DSM-III-R. While not including pornography in its context, Goodman articulated the criteria he defined for addiction as a process by which behavior works to produce inner pleasure and comfort, and operates in a pattern characterized by (1) failure to control behavior (impotence) and (2) persistence of behavior, despite the significant negative impacts(Lin et al., 2012).

In 2011, the American Society of Addiction Medicine (ASAM) issued a public statement identifying addictions (including addiction to sexual behavior) in terms of changes in the brain, chronic diseases of stimulation in the brain, motivation, memory and related nerves". The Diagnostic and Statistical Manual of Mental Disorders (DSM-V) indicates a set of behaviors that would foreshadow that an individual may be suffering from pornography addiction affects the time people used to spend on important activities such as hobbies, sports, homework, time with friends or family, etc. According to the Dell, the stages of porn use are:

- An individual's heavy pornography use when the individual feels sad, anxious, bored, or angry.

- The individual uses pornography as a way to manage and relieve stress.

- One's continuous and unsuccessful attempts to stop the use of pornography.

Insistence on continuing to use pornography even when the individual is certain that it may harm him/herself or others (loss of job opportunities, risky sexual behaviors, etc.).

- The use of pornography causes psychological distress for the individual and for others.

American Society of Addiction Medicine. (2011)

\section{Stages of Addiction on Porn Contents}

Falling into the trap of pornographic images is mostly by accident or through bad friends, and watching these pictures continues until the person falls into a kind of closed circle. This circle consists of four stages that may be repeated every day, every week or every month depending on the severity of the addiction.

The stage of justification: During this stage a person tries to find a logical justification for enables him/her to re-enter pornographic sites, such as to convince himself that $\mathrm{s} / \mathrm{he}$ spent a tired 
time this day and needs to relieve himself. This is often through phrases that $\mathrm{s} / \mathrm{he}$ convinces $\mathrm{him} /$ herself, such as saying "some minutes won't hurt, "or" I can control myself, "and s/he'll try to convince him/herself that some pictures just won't be harmful. Here, it is very similar to what happens with a cigarette smokers who convinces themselves that one cigarette will not hurt and that the can control themselves. As soon as they open the first image, the image becomes pictures, and soon enough they find themselves entering from site to site, and minutes become hours and fall into the taboos.

The regret stage: After looking at pornographic pictures and movies, which often ends with masturbation, a person experiences a phase of intense remorse. As soon as defamation occurs, a person feels severe remorse and scrupulous, and the matter may reach a state of severe depression and despair (Al-Zahrani, 2007).

The pause stage: People may completely stop watching pornographic movies and pictures and promises themselves to never return to that, followed by a short period of stopping that may be days, weeks, or even two or three months. During this period, people return to the old habits that they had, spend more time with the family, and do some sports.

The fall stage: During this stage, and after the pause, the people feel a desire to return to seeing these images, often after a tiring day or sad circumstances. They begin to forget the dangerous effects of pornography addiction and only remember the moment of pleasure they were experiencing by forgetting the pain caused. If they do not remedy the matter, the stage of justification begins and enters into a closed circle again. The increase of this period negatively correlates with the speed of the return of the fall stage from days to weeks to months until complete recovery and liberation(Al-Zahrani, 2007) .

The symptoms accompanying an addiction to watching porn movies:

1. Addiction may cause a decrease in the level of concentration, which may impair memory, and make the process of comprehension and understanding very slow. It could also make the person more likely to forget. All this leads to a decrease in the productivity of the individual addicted to watching porn movies.

2. It could cause insomnia, as well as a lack of sleep, and constant discharge as a result of being preoccupied with these films, in addition to being preoccupied with thinking thoughts far from reality, logic, or reason.

3. Addiction to pornography leads to distancing from the sociaty and family activities and a general feeling of fatigue, lethargy, laziness and a tendency to loneliness.

4. It may cause mental fatigue accompanied by irritability, irritability, excitement, and the constant feeling of severe and frequent headaches.

5. IT causes feeling pain in the back, allergy in the eyes and making them frequent

6. The addicted may feeling depressed, which is the inevitable end of addiction to pornography.

\section{Theories explaining pornography addiction}

First: Neurological theories: Neuroscientists try to develop a biological visualization that reveals the nature of addiction to pornography. They explain that when an individual looks at porn images, the feeling of pleasure associated with seeing porn scenes is directed to the brain in the neurochemical part located in the hard disk, and doctors call this process "The erotic effect of toxin".

When the individual performs a healthy behavior, or fulfills a need in, the brain sends small amounts of chemicals that make the individual feel happy and joy. This leads to satisfaction, excitement, satisfaction, etc. In addition when people see pornographic images, the mind is deceived, which leads to send large amounts of chemicals, which stimulate pleasure 
pathways in the brain, but in turn, make a person more at risk of developing pornography addiction. However, the natural sexual process paves the way for chemical addiction par excellence. There is a similarity between the effect of drugs in the brain and the effect of pornography addiction in the brain

Second: -Social learning theory: The pioneers of this theory assume that individuals learn through observation, and at the same time they only emulate behaviors that end with a reward. When pornography visualizes the sexual process, the viewer learns that this process ends with a reward for both partners in the sexual process. Also, the more likely they simulate this behavior, and the more often they simulates this behavior, the more they become accustomed to it (Kensicki, 2018).

Third: The social climate theory: This theory entails that exposure to pornography contributes to the formation of an environment in which violence against women is acceptable. This theory also assumes that this environment contains what is known as "standards or norms of pornography" and the effect of these standards is not limited to view of men to the women, but on the woman's self-awareness. In this theory, exposure to pornography leads to lower self-esteem, decreased satisfaction with body image, and a sense of defensive deficiency for women. As for men, it suffices to display excessive masculinity, and simplify the use of violence against women(Miller et al., 2016).

Third: Behavioral theory: This theory state that it is easy to get abnormal and deviant sexual disorientation in males by using sexual stimuli and other variables such as violence against children or other forms of homosexuality (sexual preference disorders). This means that the natural individual can be converted into a patient with a disorder of sexual preference, after several visits, contents are presented about it. Therefore, the increase daily work in the rates of those disorders that have long been described as rare becomes evident. Perhaps, Rackman created a type of
Fetishism in the lab in 100 males in two experiments in which their sexual arousal was linked to the fetish object, and then he removed that tape and surprised by removing this type of striping is much more difficult than expected, and some males go to that laboratory deviation (Rachman, 1968: 25)

The problem does not stop at the point of addiction. The sex addiction expert (Cline, 2000) describes four changes or stages that occur in porn addicts:

1. Addiction: As the repeated exposure to addiction causes the physical and psychological changes that result from it. Not only this, but a kind of tolerance occurs, so over time the person needs to spend longer periods of watching pornography to gain satisfaction.

2. Escalation: It refers to what is observed from the need of porn addicts to more violent, perverse, or strange material. After a period of addiction, the addicted feels bored with normal or natural sexual materials and feels the need, for example, to watch violent sex, sex with children, gays, or incest or with bisexual etc.

3. Immunization or desensitization: It refers to the changes that occur in the addicts' reaction to what they witness. What was initially considered traumatic, repulsive, annoying, rejected or forbidden, gradually becomes acceptable and very normal!

4. Sexual activation: It means an increase in the tendency over time to experiment with what is seen in the real life. Then those people get involved in behaviors such as voyeurism, group sex, child sex, rape, violence with a sexual partner, etc (Miller et al., 2016).

\section{Edward Speranger (1928) The Theory of Adolescence Interpretation}

According to Spranger (1928), teenage is not only the transition period from childhood to physiological maturity, but, more importantly - it is the age during which the relatively distorted mental structure of the child reaches full maturity. 
According to him, the "dominant value" of the individual is the deep determinant of personality (Spranger, 1928, p. 231).

Spranger's Mode has three growth patterns:

The first type was described by Spranger as a form of spiritual regeneration or rebirth in which a teenager sees him/herself as another person when reaching maturity. Scholars such Stanley Hall, and Springer believe that this period is a period of revolution, stress, and tension that leads to a fundamental change in personality similar to religious conversion.

The second mode is a slow process but the growth is continuous and the gradual acquisition of cultural values and ideas held in society, without changing the basic features (Muuss, 1988).

The third pattern is the process of growth in the individual who is actively involved. Young people consciously improve themselves and contribute to the development of their country, overcoming obstacles and crises, and this style is characterized by self-control and self-discipline. Seperanger is one of the few research scientists who directs most of their work to the teenage period. He believes that teenage is the specific period of growth that has unique characteristics different from childhood and adulthood (Muuss, 1988).

\section{Part Three}

\section{Methodology}

First: Research population: The current research population is the middle school students for the academic year (2018-2019), as their number was (25599) male and female students, (14586) males, and (9953) females (1). They are distributed among schools Al-Karkh in Baghdad province.

Second: The Research Sample: The researcher used the random method in selecting the research sample, in Karkh was identified in Baghdad. Then the researcher selected middle schools randomly, and from each school, (100) students, as (400) male and female students were selected from four schools, with (200) male and (200) female students, and table (1) illustrates this.

Table (1) Distribution of the basic application sample according to the middle schools and the gender variable

\begin{tabular}{|l|l|l|l|}
\hline \multirow{2}{*}{ Schools } & \multicolumn{2}{|l|}{$\begin{array}{l}\text { Number of second year } \\
\text { students in middle schools }\end{array}$} & \multirow{2}{*}{ total } \\
\cline { 2 - 3 } & Male & Females & \\
\hline Al-nasrya & 100 & - & 100 \\
\hline Thurat Al-Hjarahara & 100 & - & 100 \\
\hline Khadyja AL Kubra & - & 100 & 100 \\
\hline Tuinis & - & 100 & 100 \\
\hline Total & 200 & 200 & 400 \\
\hline
\end{tabular}

1 The researcher obtained the numbers of students from the Department of Educational Planning / Division of Research and Studies in the Ministry of Education

Third: - The research tool: - The following is a review of the stages of building the pornography addiction scale:

A- Collecting and drafting the items: When researcher determined the theoretical definition of porn addiction, she started the process of collecting the items from the previous measures and tools related to the topic of the research. The researcher also created items through the accumulated knowledge she had in the research variables and thus (37) items were included.

B. Determining alternatives and their weights: After completing the drafting of the items, the researcher determined the alternatives to measure 
the addiction to pornography and its weights depending on the binary alternatives by placing three alternatives in front of each items. They are: apply to me a lot, apply to me to some extent, do not apply to me with their weights. Weights are $: .1,2,3$.

$\mathrm{T}$ - numbers of scale instructions: One of the conditions for preparing standards is that the scale instructions that were built are clear and easy. So the researcher asked the respondents to answer the instructions and items with sincerity and frankness for the purposes of scientific research. The answers were anonymized and the answers will only be seen by anyone the researcher concealed the goal from the scale, so that the respondent would not be affected by it when answering, and the application sample was asked to answer without leaving any items.

W- Clarity of the scale instructions and items: For the purpose of knowing the clarity of the items of the pornography addiction scale, its alternatives, instructions and calculating the time taken to answer, the researcher applied the pornography addiction scale on (100) students. Those students were randomly selected from the first grade, and it was found the instructions were clear, the items were understandable, and the time it took to answer ranged between was from 13-15 minutes.

C- Extracting the validity of the pornography addiction scale: Honesty is one of the important characteristics that must be taken into account in building psychological measures. The researcher extracted two types of validity for the current measure:

First: Virtual honesty: to get the best way to extract outward honesty, and for the purpose of knowing the validity of the addiction scale to pornography, the researcher presented the tool, Appendix (1) to a group of specialized experts (Appendix 2) in psychology and psychological counseling. Then, they have the aim of the study, requesting them to express their observations and opinions regarding this tool, and after collecting the opinions of the arbitrators and analyzing them using the percentage, all the items that were agreed upon are valid for all members of the jury committee in measuring what was set for measuring it. Table (3) illustrates this.

Table (2) The opinions of the arbitrators on the validity of the paragraphs of the measure of addiction to pornography

\begin{tabular}{|c|l|l|l|l|l|}
\hline $\mathrm{n}$ & Items number & \multicolumn{2}{l|}{ agreement } & \multicolumn{2}{l|}{ objections } \\
\cline { 3 - 6 } $\mathrm{o}$ & $\begin{array}{l}\text { Repeti } \\
\text { tion }\end{array}$ & rate & $\begin{array}{l}\text { Repeti } \\
\text { tion }\end{array}$ & rate \\
\hline 1 & $\begin{array}{l}1.2 .3 .4 .5 .6 .8 .10 .12 .15 .21 .22 .23 .7 .9 .10 .25 .26 .28 . \\
36.37,31.32 .24 .33\end{array}$ & 10 & $\% 100$ & - & - \\
\hline 2 & 11.13 .14 .16 .17 .18 .19 .20 .27 .29 .30 .34 .35 & 8 & $\% 80$ & 2 & $\% 20$ \\
\hline
\end{tabular}

Second: - The validity of the structure: This type of honesty shows the extent of the relationship between the theoretical basis of the scale and the items of the scale. This means the extent to which the scale measures the theoretical hypotheses on which the scale is built, and this type of validity is sometimes called the validity of the hypothetical formation, and it can be verified. One of the indications of the validity of the construction of the scale is by following the method of distinguishing the item. It means the extent of the correlation of each item of the scale or the ability of the scale to distinguish between groups or groups that differ in terms of their performance on the aspect of behavior. To achieve this, the researcher applied the addiction scale to pornography with its (37) items on a sample 200 male and female students. The researcher followed two methods in the process of distinguishing the items:

The first method: - The two extremes, in this method two extreme groups of individuals are 
chosen, based on the scores they obtained on the scale. To achieve this in the current research, the researcher corrected the questionnaires, arranging the grades in descending order from the highest degree to the lowest degree. Only (27\%) were selected of the forms that obtained the highest scores, and their number was (54), and (27\%) of the forms that obtained the lowest scores, and their number was (54) forms. The lowest and highest $(27 \%)$ proportions provide two best possible groups in terms of size and differentiation. After using the T-test for two independent samples, and by comparing the extracted $\mathrm{T}$ values with the tabular value of $(1,960)$ at the level of significance $(0.05)$ and the degree of freedom (156), it was found that there are three unmarked items, which are 15, 26 and 32 Tables

illustrate

this.

Table (3) T-values of the items of the Pornography Addiction Scale, the two extreme-sample method

\begin{tabular}{|l|l|l|l|l|l|l|l|}
\hline no & T-values & no & T-values & no & T-values & no & T-value \\
\hline 1 & 3.264 & 10 & 3.369 & 19 & 2.347 & 28 & 5.284 \\
\hline 2 & 6.224 & 11 & 4.458 & 20 & 6.900 & 29 & 7.623 \\
\hline 3 & 4.310 & 12 & 2.340 & 21 & 7.559 & 30 & 4.524 \\
\hline 4 & 3.542 & 13 & 6.358 & 22 & 9.765 & 31 & 5.989 \\
\hline 5 & 7.520 & 14 & 9.564 & 23 & 7.498 & 32 & 1.360 \\
\hline 6 & 3.470 & 15 & 1.776 & 24 & 3.856 & 33 & 3.985 \\
\hline 7 & 5.632 & 16 & 3.112 & 25 & 4.118 & 34 & 7.882 \\
\hline 8 & 4.005 & 17 & 8.561 & 26 & 1.599 & 35 & 4.62 \\
\hline 9 & 6.709 & 18 & 6.890 & 27 & 5.647 & 36 & 6.530 \\
\hline
\end{tabular}

The second method: - Pearson correlation coefficient was used to find the correlation between the scores of each item with the total score of the scale for (200) questionnaires. The results showed that all correlation coefficients are statistically significant function when compared to the value of the tabular correlation coefficient at a significant level (0.05) except item 15, 26 and 32, as shown in Tables.(5 )

Table (4) Correlation coefficients between each paragraph of the Scale of Pornography Addiction and the overall score

\begin{tabular}{|l|l|l|l|l|l|l|l|}
\hline no & $\begin{array}{l}\text { Correlation } \\
\text { coefficients }\end{array}$ & no & $\begin{array}{l}\text { Correlation } \\
\text { coefficients }\end{array}$ & no & $\begin{array}{l}\text { Correlation } \\
\text { coefficients }\end{array}$ & no & $\begin{array}{l}\text { Correlation } \\
\text { coefficients }\end{array}$ \\
\hline 1 & 0.36 & 10 & 0.35 & 19 & 0.34 & 28 & 0.30 \\
\hline 2 & 0.45 & 11 & 0.50 & 20 & 0.30 & 29 & 0.45 \\
\hline 3 & 0.88 & 12 & 0.45 & 21 & 0.50 & 30 & 0.30 \\
\hline 4 & 0.46 & 13 & 0.45 & 22 & 0.33 & 31 & 0.36 \\
\hline 5 & 0.30 & 14 & 0.52 & 23 & 0.56 & 32 & 0.07 \\
\hline 6 & 0.30 & 15 & 0.14 & 24 & 0.98 & 33 & 0.31 \\
\hline 7 & 0.52 & 16 & 0.45 & 25 & 0.55 & 34 & 0.32 \\
\hline 8 & 0.40 & 17 & 0.88 & 26 & 0.12 & 35 & 0.80 \\
\hline 9 & 0.45 & 18 & 0.65 & 27 & 0.90 & 36 & 0.40 \\
\hline
\end{tabular}

C- Consistency of the scale

www.psychologyandeducation.net
1. Test - Retest: To extract consistency, the researcher re-applied the scale on a sample 
of research (60) individuals, (30) males and (30) females. The time period between the first application and the second application was ten days, and then computed the Pearson coefficient between the scores of individuals in the two applications, which reached (0.84). It can be said that the current scale has a high degree of consistency.

2. Split- Half: Pearson correlation coefficient was used to find out the relationship between individual and marital items of the pornography addiction scale, and the correlation coefficient between them reached (0.81). After correcting it using the Spearman - Brown equation, the reliability coefficient of the scale was (0.93).

Fourth: Final Application: The researcher distributed the scale of pornography addiction (Appendix / 3) to the members of the main applied research sample consisting of (400) male and female students.

Fifth: Statistical methods: - The data were processed statistically by using the statistical bag (SPSS) in the computer and by adopting the following statistical methods:
1. The test equation for the significance of the two-chain correlation coefficient.

2. Pearson's correlation coefficient.

3. T-test for one sample.

4. T-test for two independent samples.

\section{Part Four}

Results

First: - Presenting and discussing the results

\section{Learn about pornography addiction among middle school teenagers.}

In order to achieve the first objective of the current research, which aims to identify addiction to pornography among teenagers, the measure of addiction to pornography was applied to the sample of (400) males and females. T-test was done for one sample. The students obtained an arithmetic mean of (70.7675) degrees and a standard deviation of (10.15832) degrees. The hypothetical average was (68) and by calculating the $\mathrm{T}$ value of one sample whose value was (5.449), which is greater than the tabular $\mathrm{T}$ value $(1,960)$ at the level of significance (0.05) and with a degree Freedom (399) to indicate that there are differences between the sample mean and the hypothetical mean, and in favor of the sample mean. Table (5) illustrates this.

Table (5) The T-test for the differences between the mean of the sample scores and the hypothetical mean

\begin{tabular}{|l|l|l|l|l|l|l|l|}
\hline Sample & no & $\begin{array}{l}\text { Arithmeti } \\
\text { c mean }\end{array}$ & $\begin{array}{l}\text { Standard } \\
\text { deviation }\end{array}$ & $\begin{array}{l}\text { hypoth } \\
\text { etical } \\
\text { averag } \\
\text { e }\end{array}$ & $\begin{array}{l}\text { Calculated } \\
\text { T value }\end{array}$ & $\begin{array}{l}\text { tabular T } \\
\text { value }\end{array}$ & $\begin{array}{l}\text { level of } \\
\text { significan } \\
\text { ce (0.05) }\end{array}$ \\
\hline Teenagers & 400 & 70.7675 & 10.15832 & 68 & 5.449 & 1,960 & دالة \\
\hline
\end{tabular}

The current research sample has watched pornographic material repeatedly. Thus, the repeated exposure to pornography causes physical and psychological changes that result in watching pornography, including addiction, and not only this, but something like endurance occurs. Therefore, the person needs more time to spend longer periods of watching pornography to gain gratification.

\section{Screening for people with pornography addiction}

To achieve the second aim of the research, in the detection of those with porn addiction, (132) male and female students who suffer from porn addiction were detected. The males were (79) and the females were (53). By comparing their arithmetic mean of (74.5227) with the hypothetical mean of 68 and a standard deviation 
of (11.40809), and after using the T-test for one sample, the calculated $\mathrm{T}$ value reached (6.569). This value is greater than the tabular $\mathrm{T}$ value $(1,960)$ at a level of significance $(0.05)$ and with a degree of freedom (131), indicating that there are differences between the mean of people with pornography addiction and the hypothetical average, and table (6) illustrates this.

Table (6) A T-test for the significance of differences between mean scores for pornography addiction and a hypothetical sample mean (6)

\begin{tabular}{|l|l|l|l|l|l|l|l|}
\hline Sample & no & $\begin{array}{l}\text { Arithmeti } \\
\text { c mean }\end{array}$ & $\begin{array}{l}\text { Standard } \\
\text { deviation }\end{array}$ & $\begin{array}{l}\text { hypoth } \\
\text { etical } \\
\text { averag } \\
\text { e }\end{array}$ & $\begin{array}{l}\text { Calculated } \\
\text { T value }\end{array}$ & $\begin{array}{l}\text { tabular T } \\
\text { value }\end{array}$ & $\begin{array}{l}\text { level of } \\
\text { signific } \\
\text { ance } \\
(0.05)\end{array}$ \\
\hline Addicted people & 132 & 74.5227 & 11.40809 & 68 & 6.569 & 1.96 & $\begin{array}{c}\text { Statisti } \\
\text { cally } \\
\text { signific } \\
\text { ant }\end{array}$ \\
\hline
\end{tabular}

People with pornography addiction 13274.5227 11.40809686 .5691 .96 is statistically a function

It is evident from the above table that there are significant differences between the average of people with porn addiction and the hypothetical average in favor of the sufferers. This is due to the fact that escape from reality due to daily stress, increased leisure time, and the inability to social adaptation and as a result of alienation. This results in self-centeredness, a denial of reality as long as addiction to pornography and the absence of religious faith is the leader of the situation. It is caused by the openness that teenagers seek to build emotional relationships that are the spark for the outbreak of the war of sexual perversion in all its forms.

3. The differences in addiction to pornography are known according to the gender variable (male-female).

The arithmetic mean of the male sample on the pornography addiction scale was (77.0506) and the standard deviation (11.31246), while the arithmetic mean of the female sample was on the same scale (70.7547) and the standard deviation (0.70938). After applying the T-test for two independent samples, the calculated $\mathrm{T}$ value was found to be ( 12).

Table) 7(The T-test for the significance of the differences between the average degree of people with porn addiction according to the gender variable

\begin{tabular}{|c|c|c|c|c|c|c|}
\hline Gender & no & $\begin{array}{l}\text { Arithmetic } \\
\text { mean }\end{array}$ & $\begin{array}{l}\text { Standard } \\
\text { deviation }\end{array}$ & $\begin{array}{l}\text { Calculated } \\
\mathrm{T} \text { value }\end{array}$ & $\begin{array}{l}\text { tabular } \\
\mathrm{T} \text { value }\end{array}$ & $\begin{array}{l}\text { level of } \\
\text { significance } \\
(0.05)\end{array}$ \\
\hline Males & 79 & 77.0506 & 11.31246 & \multirow[t]{2}{*}{3.217} & \multirow[t]{2}{*}{1.96} & $\begin{array}{l}\text { Statistically } \\
\text { significant }\end{array}$ \\
\hline Females & 53 & 70.7547 & 10.57011 & & & \\
\hline
\end{tabular}

The result of the current research indicates that males are more addicted to pornography and therefore are more searching for that pornography. Also, they are more seeking to use the Internet in search of satisfying the sexual instinct and obtaining pleasure due to the increase in leisure time, emotional deprivation and some life pressures they are going through. However, females are fewer due to the restrictions and customs imposed on them by the family and the 
nature of social responsibility entrusted to them, and if found among females they are less than males.

\section{Recommendations}

Based on the results of the current research, the researcher recommends the following- :

1 .Teacher school administrations should monitor students who suffer from poor concentration, insomnia, lack of sleep, mental fatigue, and a decrease in academic achievement, in order to diagnose cases suffering from porn addiction. They are encouraged to guide and encourage them to review the consulting clinic in hospitals for psychiatric treatment.

2 .Opening special educational sessions in the field of dealing with, and preventing, cases of porn addiction among teenagers.

3 .Working on occupying teenagers' leisure time with useful activities in order to eliminate free time and prevent them from resorting to activities that may harm their mental health, such as sitting in front of the Internet or television for long times in which it facilitates their exposure to pornographic materials.

4 The establishment of psychological clinics, mental health counseling centers in schools, social and youth institutions, training their supervisors to use various methods to treat mental disorders are recommended.

\section{Suggestions}

The researcher proposes to conduct the following studies- :

1. Building a counseling program to alleviate symptoms of porn addiction among teenagers.

2 .The use of the scale prepared in the current research to diagnose cases of addiction to pornography.

3 .Conducting a study aimed at identifying the relationship between upbringing techniques and porn addiction
4.Conducting a study aimed at identifying the relationship between emotional deprivation and porn addiction.

\section{References}

[1] Al-Najjar, Y. M. (2009). Factors leading to frustration among the Palestinian teenager after the war on Gaza Gaza: Al-Aqsa University.

[2] Al Madani, Adel (2008) The Diary of a Teenager, Evangelical Organization for Social Services.

[3] Al-Zahrani, H. B. A. R. (2007). The Ethical Evil and Accountability of the Internet The Higher Institute for Enjoining Good and Forbidding Evil.: The Higher Institute for Enjoining Good and Forbidding Evil

[4] Al-Rifi, Muhammad (2012) Porn addiction, an article published on the internet

[5] Alavi, S. S., Maracy, M. R., Jannatifard, F., \& Eslami, M. (2011). The effect of psychiatric symptoms on the internet addiction disorder in Isfahan's University students. Journal of research in medical sciences: the official journal of Isfahan University of Medical Sciences, 16(6), 793.

[6] American Society of Addiction Medicine. (2011). Public Policy Statement: Definition of Addiction

[7] Baker, K. E. (2016). Online pornographyShould schools be teaching young people about the risks? An exploration of the views of young people and teaching professionals. Sex Education, 16(2), 213228.

[8] Beyens, I., Vandenbosch, L., \& Eggermont, S. (2015). Early adolescent 
boys' exposure to Internet pornography: Relationships to pubertal timing, sensation seeking, and academic performance. The Journal of Early Adolescence, 35(8), 10451068.

[9] Bloom, Z. D., Gutierrez, D., \& Lambie, G. W. (2017). An analysis of the factor structure and validity of the Attitudes Toward Erotica Questionnaire with a sample of counseling professionals. Measurement and Evaluation in Counseling and Development, 50(1-2), 3547.

[10] Carroll, J. S., Padilla-Walker, L. M., Nelson, L. J., Olson, C. D., McNamara Barry, C., \& Madsen, S. D. (2008). Generation XXX: Pornography acceptance and use among emerging adults. Journal of adolescent research, 23(1), 6-30.

[11] Cavaglion, G. (2009). Cyber-porn dependence: voices of distress in an Italian internet self-help community. International journal of mental health and addiction, 7(2), 295-310.

[12] Downs, M. (2005). Is pornography addictive? Psychologists debate whether people can have an addiction to pornography. In.

[13] Ferguson, F. (2004). Pornography, the theory: What utilitarianism did to action: University of Chicago Press.

[14] Hardy, S. A., Steelman, M. A., Coyne, S. M., \& Ridge, R. D. (2013). Adolescent religiousness as a protective factor against pornography use. Journal of Applied Developmental Psychology, 34(3), 131139.

[15] Lin, F., Zhou, Y., Du, Y., Qin, L., Zhao, Z., Xu, J., \& Lei, H. (2012). Abnormal white matter integrity in adolescents with internet addiction disorder: a tract-based spatial statistics study. PloS one, 7(1), e30253.

[16] Madani, A. (2008). he Diary of a Teenager.

[17] Mesch, G. S. (2009). Social bonds and Internet pornographic exposure among adolescents. Journal of adolescence, 32(3), 601-618.

[18] Miller, A. N., Nalugya, E., Gabolya, C., Lagot, S., Mulwanya, R., Kiva, J., . . . Chibita, M. (2016). Ugandan adolescents' sources, interpretation and evaluation of sexual content in entertainment media programming. Sex Education, 16(6), 707720.

[19] Muuss, R. E. (1988). Theories of adolescence: Crown Publishing Group/Random House.

[20] Ohuakanwa, Chijioke Ephraim; Omeje, Joachim Chinweike; Eskay, Michael(2012) New Prof Omeje Pornography Addiction as Correlate of Psychosocial and Academic Adjustment of Students in Universities in Lagos State,Online Submission, US-China Education Review B 11 p907-920

[21] Ohuakanwa, Chijioke Ephraim; Omeje, Joachim Chinweike; Eskay, Michael(2012) New Prof Omeje Pornography Addiction as Correlate of Psychosocial and Academic Adjustment of Students in Universities in Lagos State,Online Submission, US-China Education Review B 11 p907-920

[22] O'Reilly, S., Knox, D., \& Zusman, M. E. (2007). College student attitudes toward pornography use. College Student Journal, 41(2), 402-407. 
[23] Oravec, J. A. (2000). Internet and computer technology hazards: Perspectives for family counselling. British Journal of Guidance \& Counselling, 28(3), 309-324.

[24] Paolucci, E., Genuis, M., \& Violato, C. (2000). A meta-analysis on the published research on the effects of pornography. In C. Violato, E. Oddone-Paolucci, \& M. Genuis (Eds.), The changing family and child development. (pp. 48-59). Aldersgate UK: Ashgate Publishing.

[25] Rachman S. (1968) Phobias: Their Nature And Control. Thomas, Springfield.D

[26] Romit, P., \& Beltramini, L. (2015). Factors associated with exposure to violent or degrading pornography among high school students. The Journal of School Nursing, 31(4), 280-290.

[27] Spranger, E. (1928). Types of men (PJW Pigors, Trans.). Halle: Max Niemeyer Verlag.(German original first printing 1920).

[28] Svedin, C. G., Åkerman, I., \& Priebe, G. (2011). Frequent users of pornography. A population based epidemiological study of Swedish male adolescents. Journal of adolescence, 34(4), 779-788

[29] Wetterneck, Chad T,Angela J. Burgess, Mary B. Short, Angela H. Smith, and Maritza E. Cervantes(2012) The Role of Sexual Compulsivity, Impulsivity, and Experiential Avoidance in Internet Pornography Us e, The Psychological Record, 2012, 62, 3-18

[30] Wikipedia, the free encyclopedia 